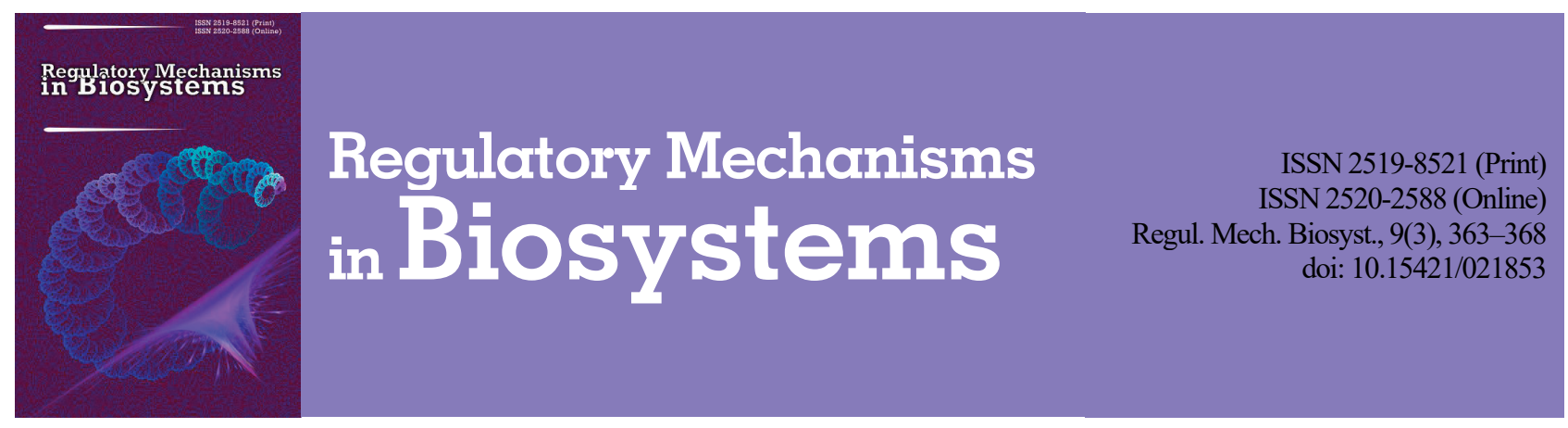

\title{
BoLA-DRB3 gene as a marker of susceptibility and resistance of the Ukrainian black-pied and red-pied dairy breeds to mastitis
}

\author{
T. M. Suprovych, M. P. Suprovych, T. V. Koval, T. M. Karchevska, \\ V. A. Chepurna, I. O. Chornyi, A. P. Berezhanskyi \\ State Agrarian and Engineering University in Podilya, Kamianets-Podilskyi, Ukraine
}

Article info

Received 01.08.2018

Received in revised form 29.08.2018

Accepted 02.09.2018

State Agrarian and Engineering University in Podilya, Shevchenko st., 13, Kamianets-Podilski, 32300, Ukraine.

Tel.: +38-098-57-63-018

E-mail: suprovycht@gmail.com

Suprovych, T. M., Suprovych, M. P., Koval, T. V., Karchevska, T. M., Chepurna, V. A., Chornyi, I. O., \& Berezhanskyi, A. P. (2018). BoLA-DRB3 gene as a marker of susceptibility and resistance of the Ukrainian black-pied and red-pied dairy breeds to mastitis. Regulatory Mechanisms in Biosystems, 9(3), 363-368. doi:10.15421/021853

The major histocompatibility complex (MHC) determines the immune response, and the MHC genes are promising candidate genes for identifying associations with diseases. The decisive role in the resistance of cattle to diseases belongs to the major histocompatibility complex of (BoLA). The BoLA system consists of several jointly operating genes that provide antigen presentation by MHC system molecules followed by an immune response to pathogenic microorganisms. The most functional is the BoLA-DRB3 gene. Its exon 2 is highly polymorphic and encodes the peptide antigen-binding cleft. Alleles, for which a close connection with disease susceptibility or disease resistance has been detected, are considered as DNA markers. These play a decisive role in the breeding of cattle to create herds resistant to diseases, including mastitis. This paper presents the results of a study of BoLA-DRB3 gene polymorphism in two commercial cattle breeds: the Ukrainian black-pied dairy (UBPD) and the Ukrainian red-pied dairy (URPD) and its association with mastitis. The UBPD and the URPD cows were genotyped at the bovine lymphocyte antigen DRB3.2 locus by a genotyping system that used polymerase chain reaction and restriction fragment length polymorphisms (PCR-RLFP). In 276 UBPD cows, 32 BoLA-DRB alleles have been found. Six alleles $(* 03, * 08, * 10, * 22, * 24$ and *28) were identified with a frequency of more than $5 \%$ (total amount of $50.4 \%$ ). The allele BoLA-DRB3.2*24 was the most frequent $(19.2 \%)$. In the UBPD population $(n=162)$, four BoLA-DRB3.2 alleles are truly associated with mastitis: *24 and *26 with susceptibility and $* 13$ and $* 22$ with resistance. In 117 URPD cows, 22 alleles were identified, of which the most frequent were $* 07, * 22, * 11, * 24, * 01, * 03$ and $* 16$ (total frequency $64.5 \%$ ). Allele BoLA-DRB3.2*07 (present in $25.6 \%$ of cows) was the most commonly found. In the URPD population studied, four alleles truly associated with mastitis were identified. Animals susceptible to the disease had alleles $* 07$ and $* 08$, and resistant animals had alleles $* 22$ and $* 24$. Breeding activities for the creation of cattle resistant to mastitis using alleles of the BoLA-DRB3 gene are much more effective than treatment and special care for animals. Similar research should be carried out for other Ukrainian breeds in relation to various diseases (leukemia, necrobacteriosis, etc.).

Keywords: polymorphism; PCR-RLFP; allele-specific PCR; alleles; udder, cattle.

\section{Introduction}

Udder diseases of cows lead to significant economic loss for the dairy business. That loss is greater than any damage from all non-contagious diseases in cattle farming. Mastitis in cattle imposes a significant financial burden on milk producers (the dairy industry worldwide loses \$16-26 billion annually) (Abdel Hameed et al., 2006). Dairy production in Ukraine is the main branch of cattle farming. In 2016, 10,329 thousand tons of milk were received from 2,100 thousand cows (Chajkova \& Foshhij, 2016). Mastitis of cows represents the biggest challenge for milk producers. The analysis of data from different publications shows that cases of mastitis amount to $18.8-34.7 \%$ of livestock, including $3.62-$ $12.6 \%$ of clinically manifested cases. The loss due to the disease is about $\$ 75$ per animal (Hanjejev \& Janchuk, 2011).

The search for disease resistance markers includes the screening of candidate genes that are associated with the disease resistance caused by DNA polymorphisms. The major histocompatibility complex plays a crucial role in the immune response, and MHC genes are promising candidate genes to establish associations with various diseases (Abdel Hameed et al., 2006). MHC is a polymorphic genetic system that is a cluster of closely coupled genes. It is responsible for the formation of the immune response, macrophage, T-and B-lymphocyte interactions and for the immunological homeostasis support in general. The binding of peptides to MHC molecules triggers acquired immune responses. Therefore, MHC molecule polymorphism forms the diversity of the immune response. In particular, the major histocompatibility complex genes (BoLA) of cattle play an important role in the resistance of the host to diseases (Ibeagha-Awemu et al., 2008).

The BoLA system is located on the chromosome 23. It includes three classes: class I (locus A); class II, divided into IIa (includes DRA, DRB1, DRB3, DRB2, DQA DQB et al. loci) and IIb (includes DOB, DYA, DYB, DIB et al. loci); class III (including TNF, 21-OH, C4, BF, HSP70-1 and -2, EAM, PRL et al. loci). The first two groups of loci encode surface molecules that are related to the induction and regulation of immune responses.

The BoLA-DRB3 gene encoding antigens of Class II MHC is quite polymorphic (Van Eijk et al., 1992; Sharif et al., 1998). It is located in the IIa region of the sublocus of the DR system BoLA. The gene consists of six exons encoding the leader and the terminal sequence, the hydrophobic transmembrane region, the cytoplasmic and extracellular domain of the protein. The second exon of the BoLA-DRB3 gene encoding the $\beta_{1}$-domain of class II antigens is highly polymorphic. This is 
necessary for binding of a wide range of foreign antigens (Behl et al., 2012). Analysis of the BoLA-DRB3.2 gene polymorphism is performed by PCR-RLFP (54 alleles) or PCR-SBT (107 alleles according to www.ebi.ac.uk/ipd/mhe/group/BoLA).

The functions of MHC antigens, associated with immune response to foreign antigens, determine numerous associations with specific diseases. Therefore, most studies are devoted to the establishment of the relation of the alleles of BoLA-DRB3.2 gene to various diseases: mastitis (Dietz et al., 1997; Sharif et al., 1998; Rupp et al., 2007; Kulberg et al., 2007; Duangjinda et al., 2009; Firouzamandi et al., 2010), dermatophilosis (Maillard et al., 1996), lameness (Sun et al., 2013), FMD (footand-mouth disease) (Lei et al., 2012), leukemia (Udina et al., 2003; Nikbakht Brujeni et al., 2016; Latypova et al., 2017), tick-borne disease (Duangjinda et al., 2013).

The BoLA-DRB3.2 gene polymorphism has been studied in more than 30 cattle populations (Takeshima et al., 2014) and the research is on-going. The allelic spectrum of the gene for most commercial breeds has been identified. The greatest attention of researchers is given to the purebred Holstein in the USA and Canada (Dietz et al., 1997; Sharif et al., 1998; Rupp et al., 2007) and to the breeds in other countries with a significant proportion of heredity from the Holstein (Duanginda et al., 2009; Yoshida et al., 2012; Sun et al., 2013; Takeshima et al., 2015; Nikbakht Brujeni et al., 2016). There are numerous reports on the study of allelic diversity of indigenous breeds: Norwegian Red (Kulberg et al., 2007), Russian Ayrshire and Black-Pied (Udina et al., 2003), Japanese Shorthorn (Takeshima et al., 2002), USA Jersey (Gilliespie et al., 1999). Considerable attention is given to the study of the BoLA-DRB3.2 gene polymorphism in indigenous and native breeds: China Wanbei (Lei et al., 2012), Philippine native cattle (Takeshima et al., 2014), cattle of South American (Giovambattista et al., 2001; Takeshima et al., 2015), Mongolian, Kalmyk and Yakut breeds (Ruzina et al., 2010), Iranian native cattle (Firouzamandi et al., 2010), Indian native cattle (Behl et al., 2009), Egyptian cows (Ibrahim et al., 2012).

There are many breeds for which polymorphism of the BoLADRB3 gene and its connection with diseases has not been studied. The present study is aimed at analyzing the polymorphism of the BOLA-DRB3 gene exon 2 of the most common Ukrainian dairy breeds, black-pied dairy and red-pied and establishing associations between the alleles of this gene and mastitis.

\section{Materials and methods}

The research was carried on farms in Khmelnitsky and Chernivtsi regions from 2009 until 2015. Blood samples from the UBPD breed ( 5 farms, $n=276$ ) and the URPD breed ( 2 farms, $n=117$ ) were examined. Practical studies we conducted at the Animal Genetics Laboratory at the Institute of General Genetics Vavilov Russian Academy of Sciences (Moscow) and in the Genetics Laboratory of the Institute of Animal Breeding and Genetics of National Academy of Agrarian Science of Ukraine.

The maximum accuracy of the alleles of the gene BoLA-DRB3 definition was achieved by using three independent approaches (Sulimova, 2004):

- restriction analysis of PCR-RFLP amplification products;

- allele-specific PCR (AS-PCR) with primers ER-17 and VD-19;

- allele-specific PCR with primers HLO-07 and HLO-24d.

Isolation of DNA was carried out using "DIAtomTMDNA Prep200" kits (Isogen Laboratory Ltd.) in accordance with the manufacturer's instructions. DNA isolated from fresh biological material (yield was $5-10 \mathrm{mg}$ from $200 \mathrm{ml}$ of whole blood) high molecular weight (40-50 bp) and pure (OD 260/280 $\mathrm{nm}=1.6-2.0$ ) substance. The DNA concentration was determined visually. With this purpose, 25,50 , and $100 \mathrm{ng}$ of $\lambda$ phage DNA and aliquots of solution with an unknown concentration were applied to $1 \%$ agarose gel.

Electrophoresis was performed in $1^{\mathrm{x}}$ Trisborate (TBE) buffer $(89 \mathrm{mM}$ Tris-OH, $89 \mathrm{mM} \mathrm{H} \mathrm{H}_{3} \mathrm{BO}_{3}, 2 \mathrm{mM}$ EDTA) with ethidium bromide $(1 \mu \mathrm{g} / \mathrm{ml})$ added to the gel to stain DNA at a constant voltage of $120 \mathrm{~V}$. To avoid contamination, electrophoresis was performed in a separate room.

The DNA concentrations of the test samples were determined by comparing the fluorescence intensity of the aliquots from solutions of unknown concentration and control $\lambda$ phage DNA. For further nested PCR analysis, the exon 2 region of the BoLA-DRB3 gene, $284 \mathrm{bp}$ in size, was amplified (281 bp for alleles with deletion) (Van Eijk et al., 1992).

The PCR was carried out using ready-made sets of "GenPakR PCR Core", LLC "Izogen Laboratory", Russia. The final volume of the reaction mixture was $20 \mu \mathrm{l}$. The mixture contained $60 \mathrm{mM}$ Tris-HCL (pH 8.8), $2.5 \mathrm{mM} \mathrm{MgCl} 2,20 \mathrm{mM} \mathrm{KCl}, 15 \mathrm{mM}\left(\mathrm{NH}_{4}\right)_{2} \mathrm{SO}_{4}, 10 \mathrm{mM}$ mercaptoethanol, $0.1 \%$ Triton X-100, $0.2 \mathrm{mM}$ dNTP, 10 units of Klentaq DNA polymerase, $10 \mathrm{pM}$ of each primer, template DNA. Oligonucleotide primers used for amplified of the exon 2 of BoLADRB3 were previously published (Van Eijk et al., 1992). The primers HLO-30 (5'-3': TCCTCTCTCTGCAGCACATTTCC) and HLO-31 (5'-3': ATTCGCGCTCACC TCGCCGCT) for the first round of the reaction were used. $5 \mu \mathrm{DNA}$ was used as a template, regardless of its concentration. For the second round, PCR primers HLO-30 (5'-3': TCCTCTCTCTGCAGCACATTTCC) and HLO-32 (5'-3': TCGCCGCTGCACAGT GAAACTCTC) were used. $2 \mu \mathrm{l}$ of the first round PCR products were used for the second round.

Amplification. The first stage was started from DNA denaturation at $95^{\circ} \mathrm{C}$ for $5 \mathrm{~min}$. followed by 10 cycles with denaturation $\left(94^{\circ} \mathrm{C}\right.$ for $1 \mathrm{~min})$, annealing $\left(62.5^{\circ} \mathrm{C}\right.$ for $\left.2 \mathrm{~min}\right)$ and elongation $\left(72^{\circ} \mathrm{C}\right.$ for $\left.1 \mathrm{~min}\right)$ and a final extension at $72^{\circ} \mathrm{C}$ for $7 \mathrm{~min}$. The second stage was started initial denaturation $\left(95^{\circ} \mathrm{C}\right.$ for $\left.5 \mathrm{~min}\right)$, was followed by 35 cycles of denaturation $\left(68^{\circ} \mathrm{C}\right.$ for $\left.30 \mathrm{~s}\right)$, and annealing-extension $\left(72{ }^{\circ} \mathrm{C}\right.$ for $\left.30 \mathrm{~s}\right)$ and a final extension $\left(72{ }^{\circ} \mathrm{C}\right.$ for $\left.7 \mathrm{~min}\right)$. Contamination and self-priming controls were included in each PCR round and $5 \mu \mathrm{L}$ of the last PCR product were electrophoresed on $1.5 \%$ agarose gels in order to check the quality and specificity of DNA fragment amplification.

For the restriction analysis of the exon 2 fragment of the BoLADRB3 gene, endonucleases Rsal, HaeIII, XholI (Promega, USA, New England BioLabs and SibEnzim, Russia) were used. The restriction fragments were separated by electrophoresis in a $4 \%$ agarose gel (Fig. 1). Amplification of exon 2 of the gene by means of a PCR followed by the analysis of restriction fragment length polymorphism and comparison of DNA patterns obtained using the three specified restriction endonucleases allows the identification of 54 alleles of the BoLA-DRB3 gene.

In cases where it was impossible to determine the genotype of the animal using restriction analysis, the AS-PCR method was used (Fig. 2). Allelic variants differ because the 3'-terminal nucleotide of one of the primers hybridizes directly to the variable nucleotide (SNP position), which causes the presence or absence of PCR. The specificity of the reaction can be increased by introducing an additional, not paired, nucleotide in the second or third position from the 3'-end of the same primer or using a competitive PCR in the same tube. Allele-specific PCR was performed using ready-made sets of "GenPakR PCR Core" (Isogen Laboratory). The PCR products of the first round of nested PCR were used as a template. A more detailed description of the method for typing the DRB3-alleles was reported by other sources (Udina et al., 2003; Firouzamandi et al., 2010; Ruzina et al., 2010).

Cows which repeatedly suffered during $2-3$ lactations from various forms of mastitis were considered susceptible to mastitis. Animals which had no disease during this period were considered resistant.

In order to detect which cows were resistant and which were sensitive to mastitis, we conducted regular monthly studies. Special control plates with four deepenings were used. In these deepenings $1 \mathrm{ml}$ of milk from each udder quarter and equal amounts of reagent were added. If the reaction was positive, a jelly-like clot formed, which indicated the presence of at least 500 thousand somatic cells per $1 \mathrm{ml}$ of milk. Clinical manifestations of mastitis were diagnosed during milking based on several factors, such as: proportionality of udder quarters, pain sensitivity, local and general temperature increases, swelling, udder induration, secretion and presence of blood or pus in the secretrion.

Allele frequencies for the experimental sample were calculated taking into account the number of homozygotes and heterozygotes. In order to identify the associations between BoLA-alleles and the disease, it is necessary to establish the strength of association and the statistical significance between the frequency of gene carriers in the groups of susceptible and resistant animals. The force of the associative relationship is determined on the basis of relative risk ( $R R$ - relative risk, $f_{b}-$ 
frequency of gene carriers among susceptible animals, $f_{k}-$ frequency of gene carriers in resistant animals):

$$
R R=\frac{f_{b}\left(1-f_{k}\right)}{f_{k}\left(1-f_{b}\right)}
$$

The RR value shows how many times the risk of developing the disease is greater in the presence of a certain allele in the genotype than in its absence (Zaretskaya, 1983).

Test $\chi^{2}$ indicates a statistically significant difference between the frequency of alleles among susceptible and resistant animals. The allele is considered as associated with the disease if the condition $R R \geq 2$ and $\chi^{2}>3.84(\mathrm{P}<0.05)$ is satisfied. If the value $\mathrm{RR} \leq 0.5$, then the presence of the allele in the animal genotype indicates a close association with the disease resistance. In this case, in order to highlight a positive association, relative risk values are set as $1 / \mathrm{RR}$ with a minus sign. Test $\chi^{2}$ makes sense if the sample involves at least 20 animals and the respective conditions are met (a, $\mathrm{c}$ - susceptible to animal disease, having or not having an appropriate allele; $\mathrm{b}, \mathrm{d}$ - resistant to animal disease, having or not having an appropriate allele; $\mathrm{N}$ - sample size):

$$
\begin{aligned}
& (\mathrm{a}+\mathrm{b}) \times(\mathrm{a}+\mathrm{c}) / \mathrm{N}>5,(\mathrm{a}+\mathrm{b}) \times(\mathrm{b}+\mathrm{d}) / \mathrm{N}>5, \\
& (\mathrm{c}+\mathrm{d}) \times(\mathrm{a}+\mathrm{c}) / \mathrm{N}>5,(\mathrm{c}+\mathrm{d}) \times(\mathrm{b}+\mathrm{d}) / \mathrm{N}>5 .
\end{aligned}
$$

If an allele is not detected in groups of susceptible or resistant animals, one of the values $a$ or $b$ is zero. Then the value of RR is determined by the Haldane formula (Kleinbaum et al., 1982). Woolf-Haldane correction is a modification of data, which allows for the verification of statistical significance in cases where one of the values is zero. Numeric 0.5 to warn the division by zero and make the calculation possible increases the 0 value.

\section{Results}

Polymorphism of BoLA-DRB3.2 gene in Ukrainian black-pied and red-pied dairy breeds

Ukrainian black-pied dairy breed. Table 1 summarizes the allele frequencies of the BoLA-DRB3.2 gene for 276 cows. The total number of the alleles found was 32 .

Table 1

The distribution of the frequencies of the BoLA-DRB3.2 alleles in the population of UBPD cows $(n=276)$

\begin{tabular}{cccccc}
\hline $\begin{array}{c}\text { Allele BoLA- } \\
\text { DRB3.2 }\end{array}$ & $\begin{array}{c}\text { Number } \\
\text { of alleles }\end{array}$ & $\begin{array}{c}\text { Frequency } \\
\text { P(A), } \%\end{array}$ & $\begin{array}{c}\text { Allele BoLA- } \\
\text { DRB3.2 }\end{array}$ & $\begin{array}{c}\text { Number of } \\
\text { alleles }\end{array}$ & $\begin{array}{c}\text { Frequency } \\
\text { P(A), } \%\end{array}$ \\
\hline$* 01$ & 7 & 1.27 & $* 20$ & 5 & 0.9 \\
$* 02$ & 12 & 2.17 & $* 21$ & 9 & 1.6 \\
$* 03$ & 31 & 5.62 & $* 22$ & 57 & 10.3 \\
$* 04$ & 11 & 1.99 & $* 23$ & 16 & 2.9 \\
$* 06$ & 1 & 0.18 & $* 24$ & 79 & 14.3 \\
$* 07$ & 26 & 4.71 & $* 25$ & 3 & 0.5 \\
$* 08$ & 38 & 6.88 & $* 26$ & 19 & 3.4 \\
$* 10$ & 31 & 5.62 & $* 28$ & 42 & 7.6 \\
$* 11$ & 7 & 1.27 & $* 31$ & 3 & 0.5 \\
$* 12$ & 18 & 3.26 & $* 32$ & 15 & 2.7 \\
$* 13$ & 25 & 4.53 & $* 36$ & 17 & 3.1 \\
$* 14$ & 2 & 0.36 & $* 37$ & 19 & 3.4 \\
$* 15$ & 10 & 1.81 & $* 41$ & 3 & 0.5 \\
$* 16$ & 14 & 2.54 & $* 42$ & 4 & 0.7 \\
$* 18$ & 12 & 2.17 & $* 48$ & 12 & 2.2 \\
$* 19$ & 2 & 0.36 & $* 51$ & 2 & 0.4 \\
\hline
\end{tabular}

Six alleles had frequency of more than $5 \%$ (such alleles are termed «informative»). They are alleles $* 03, * 08, * 10, * 22, * 24$ and $* 28$. Their total frequency is $50.4 \%$. The allele BoLA-DRB3.2*24 was the most frequent in the sample and was found in 53 cows. This allele was carried by $19.2 \%$ of animals (including homozygotes). Four alleles *06, $* 14, * 19$ and $* 51(\mathrm{P}(\mathrm{A})<0.5 \%)$ were the least frequent.

Ukrainian red-pied dairy breed. We studied the allelic spectrum of this breed in two herds on farms in Khmelnitsky and Chernivtsi regions. Twenty-two alleles were detected in 117 blood samples (Table 2).

Seven alleles had frequency of more than $5 \%$. They make up $64.5 \%$ of the total alleles fund of the sample studied. The most "informative" for the breed studied is the allele BoLA-DRB3.2*07, which was identified in 36 cases (15.4\%), almost every fourth animal carries it. Seven alleles
$(* 04, * 09, * 12, * 20, * 32, * 35$, and $* 43)$ were detected only thrice $(1.6 \%)$.

Table 2

The distribution of the frequencies of the BoLA-DRB3.2 alleles in the population of URPD cows $(n=117)$

\begin{tabular}{cccccc}
\hline $\begin{array}{c}\text { Allele BoLA- } \\
\text { DRB3.2 }\end{array}$ & $\begin{array}{c}\text { Number of } \\
\text { alleles }\end{array}$ & $\begin{array}{c}\text { Frequency } \\
\text { P(A), } \%\end{array}$ & $\begin{array}{c}\text { Allele BoLA- } \\
\text { DRB3.2 }\end{array}$ & $\begin{array}{c}\text { Number } \\
\text { of alleles }\end{array}$ & $\begin{array}{c}\text { Frequency } \\
\text { P(A), } \%\end{array}$ \\
\hline$* 01$ & 18 & 7.7 & $* 20$ & 3 & 1.3 \\
$* 03$ & 12 & 5.1 & $* 22$ & 31 & 13.3 \\
$* 04$ & 3 & 1.3 & $* 24$ & 20 & 8.6 \\
$* 07$ & 36 & 15.4 & $* 25$ & 6 & 2.6 \\
$* 08$ & 11 & 4.7 & $* 27$ & 6 & 2.6 \\
$* 09$ & 3 & 1.3 & $* 28$ & 8 & 3.4 \\
$* 10$ & 11 & 4.7 & $* 32$ & 4 & 1.7 \\
$* 11$ & 22 & 9.4 & $* 35$ & 3 & 1.3 \\
$* 12$ & 3 & 1.3 & $* 42$ & 11 & 4.7 \\
$* 15$ & 4 & 1.7 & $* 43$ & 3 & 1.3 \\
$* 16$ & 12 & 5.1 & $* 45$ & 4 & 1.7 \\
\hline
\end{tabular}

Determination of associative relationships between alleles and mastitis

Ukrainian black-pied dairy breed. The sample studied included 62 cows susceptible and 100 cows resistant to mastitis. In this research, we identified 28 BoLA-DRB3.2 alleles, of which 24 were present in the group of susceptible cows. Five alleles were identified with a frequency of more than $5 \%$, occupying together $53.6 \%$ of the total allele spectrum. In animals susceptible to mastitis, the allele *24 was the most frequent 20 cases (16.1\%). They were found in 17 animals (27.4\%). Alleles frequently found also include *28 $(9.7 \%), * 26(8.1 \%), * 22(7.3 \%)$, and $* 03(6.5 \%)$. The alleles $* 01, * 20$, and $* 42(0.8 \%$ for each) were found to a limited extent.

Among the cows resistant to mastitis, 27 alleles were found. The total frequency of eight "informative" alleles was $65.5 \%$. The most frequent was BoLA-DRB $3.2 * 22$ allele. It was carried by $24 \%$ of cows. The peculiarity of this allele is that it forms a homozygous genotype most often spread throughout a whole population $(40 \%$ of the total number of homozygotes detected).

The association between the disease and the allele is detected by comparing the frequencies of alleles in sick and healthy cows based on relative risk (RR), which reflects multiplicity of the association, that is, how many times the risk of developing the disease is greater in the presence of a specific allele in the genotype than in its absence. The significance of the detected association is determined by the test $\chi^{2}$. According to the relative risk associated with mastitis, there are 17 alleles, of which eight are associated with susceptibility and nine with resistance (Table 3).

Table 3

\begin{tabular}{|c|c|c|c|c|c|c|c|}
\hline \multirow{2}{*}{$\begin{array}{c}\text { Allele } \\
\text { BoLA- } \\
\text { DRB 3.2* }\end{array}$} & \multirow[b]{2}{*}{$\begin{array}{l}\text { Frequency } \\
\mathrm{P}(\mathrm{A}), \%\end{array}$} & \multirow[b]{2}{*}{$\chi^{2}$} & \multirow[b]{2}{*}{$\mathrm{RR}$} & \multicolumn{4}{|c|}{ Test $\chi_{\min }^{2}$ on the limited sample } \\
\hline & & & & $\begin{array}{l}(a+b) \times \\
(a+c) / N\end{array}$ & $\begin{array}{l}(a+b) \times \\
(b+d) / N\end{array}$ & $\begin{array}{l}(\mathrm{c}+\mathrm{d}) \times \\
(\mathrm{a}+\mathrm{c}) / \mathrm{N}\end{array}$ & $\begin{array}{l}(c+d) \times \\
(b+d) / N\end{array}$ \\
\hline$* 01$ & 0.0154 & 0.729 & -2.54 & 1.91 & 2.99 & 60.1 & 96.9 \\
\hline$* 08$ & 0.0741 & 2.1 & -2.05 & 9.19 & 13.0 & 52.8 & 85.2 \\
\hline$* 11$ & 0.0154 & 3.85 & 6.83 & 1.91 & 3.18 & 60.1 & 96.9 \\
\hline$* 13$ & 0.0525 & 5.65 & -5.29 & 6.51 & 9.13 & 55.5 & 89.5 \\
\hline *15 & 0.0185 & 2.13 & 3.38 & 2.3 & 3.78 & 59.7 & 96.3 \\
\hline$* 16$ & 0.0062 & 1.26 & -3.17 & 0.77 & 1.21 & 61.2 & 98.8 \\
\hline$* 18$ & 0.0247 & 4.81 & 5.25 & 3.06 & 5.14 & 58.9 & 95.1 \\
\hline *21 & 0.0185 & 2.13 & 3.38 & 2.3 & 3.78 & 59.7 & 96.3 \\
\hline *22 & 0.1204 & 5.02 & -2.52 & 14.9 & 19.0 & 47.1 & 75.9 \\
\hline *24 & 0.1173 & 4.33 & 2.17 & 14.5 & 23.9 & 47.5 & 76.5 \\
\hline$* 25$ & 0.0062 & 1.26 & -3.17 & 0.77 & 1.21 & 61.2 & 98.3 \\
\hline *26 & 0.0432 & 7.13 & 4.62 & 5.36 & 9.16 & 56.6 & 91.4 \\
\hline *31 & 0.0062 & 1.26 & -3.17 & 0.77 & 1.21 & 61.2 & 98.8 \\
\hline *32 & 0.0309 & 1.51 & -2.61 & 3.83 & 5.8 & 58.2 & 93.8 \\
\hline *36 & 0.0309 & 6.61 & -14.5 & 3.83 & 5.56 & 58.2 & 93.8 \\
\hline$* 41$ & 0.0062 & 3.27 & 8.31 & 0.77 & 1.26 & 61.2 & 98.8 \\
\hline$* 48$ & 0.0247 & 4.81 & 5.25 & 3.06 & 5.14 & 58.9 & 95.1 \\
\hline
\end{tabular}

Detection of BoLA-DRB3.2 alleles of UBPD cows associated with mastitis

Notes: * The Table shows the alleles for which one of the following conditions holds: 1) $\chi 2 \geq 3.8 ; 2) \mathrm{RR} \geq 2$ or $\mathrm{RR} \leq-2$; 3 ) both conditions 1 and 2 . 
Test $\chi^{2}$ determines eight alleles that have a sufficient level of reliability: *26 and *36 (P<0.01); *11, *13, *18, *22, *24, *48 (P<0.05). Only four alleles of the above withstood the check for limited sample size. Thus, four BoLA-DRB3.2 alleles were found to have a strong and true association with mastitis in the UBPD population studied. Susceptible to mastitis are cows with alleles:

BoLA-DRB3.2*24 $\left(\mathrm{RR}=2.17 ; \mathrm{P}(\mathrm{A})=0.117 ; \chi^{2}=4.33\right) ; \chi_{\text {min }}^{2}=$ true; BoLA-DRB3. $2 * 26\left(\mathrm{RR}=4.62 ; \mathrm{P}(\mathrm{A})=0.043 ; \chi^{2}=7.13\right) ; \chi_{\min }^{2}=$ true; resistant are:

BoLA-DRB3. $2 * 13\left(\mathrm{RR}=-5.29 ; \mathrm{P}(\mathrm{A})=0.053 ; \chi^{2}=5.65\right) ; \chi_{\min }^{2}=$ true; BoLA-DRB3.2*22 $\left(\mathrm{RR}=-2.52 ; \mathrm{P}(\mathrm{A})=0.12 ; \chi^{2}=5.02\right) ; \chi_{\text {min }}^{2}=$ true.

It is necessary to pay attention to alleles $* 18$ and $* 48$ with high relative risk $(\mathrm{RR}=5.25)$ and sufficient significance in the test $\chi^{2}$, but which do not satisfy the test for small sample size $\left(\chi_{\min }^{2}=\right.$ false), because they are rarely found in healthy animals. Such a restriction, as a rule, can withstand a check for small samples according to Fisher's criterion, with a slight decrease in the overall reliability of the study.

Due to the resistance to mastitis, it is necessary to pay attention to the allele $* 08(\mathrm{RR}=-2.05 ; \mathrm{P}(\mathrm{A})=0.074)$, which does not withstand the test $\chi^{2}(\mathrm{P}>0.05)$ but meets the requirements of reliability by other criteria. In case of competent biological studies, it is permissible to lower the threshold of reliability, which makes it possible to use this allele in further analysis.

Ukrainian red-pied dairy breed. Blood samples were taken from 117 animals. Fifty-nine cows were resistant and 58 susceptible to mastitis.

Twenty-one alleles were detected in the samples of diseased animals. Eight alleles with a frequency exceeding $5 \%$ were identified, which embrace in total $74.9 \%$. The most common allele was BoLADRB3.2*07. It was detected in almost every third cow $(32.8 \%)$, or in $21.6 \%$ of cases among all detected alleles.

In the group of resistant animals, 20 alleles were identified, among which the most "informative" is BoLA-DRB3.2*22. It embraces $19.5 \%$ of the allelic spectrum. Six alleles other were found with a frequency of more than 5\%: *24 (11.7\%), *11 (11.0\%), *07 (9.3\%), *01 and *16 $(5.9 \%), * 28(5.1 \%)$. The other 13 alleles embrace in total $30.5 \%$. All alleles have only the heterozygous genotype.

Relative risk calculations show that 13 alleles of BoLA-DRB3.2 have a close association with mastitis, of which eight are associated with susceptibility and five with resistance to this disease (Table 4). The test $\chi^{2}$ indicates five alleles that have a sufficient level of significance: $* 22$ $(\mathrm{P}<0.001) ;{ }^{*} 07(\mathrm{P}<0.01) ; * 08, * 24 \mathrm{i} * 45(\mathrm{P}<0.05)$, of which only the latter cannot withstand a check for limited sample size.

\section{Table 4}

Detection of BoLA-DRB3.2 alleles

of URPD cows associated with mastitis

\begin{tabular}{|c|c|c|c|c|c|c|c|}
\hline \multirow{2}{*}{$\begin{array}{c}\text { Allele } \\
\text { BoLA- } \\
\text { DRB 3.2* }\end{array}$} & \multirow[b]{2}{*}{$\begin{array}{c}\text { Frequency } \\
\text { P(A), \% }\end{array}$} & \multirow[b]{2}{*}{$\chi^{2}$} & \multirow[b]{2}{*}{$\mathrm{RR}$} & \multicolumn{4}{|c|}{ Test $\chi_{\min }^{2}$ on the limited sample } \\
\hline & & & & $\begin{array}{l}(a+b) \times \\
(a+c) / N\end{array}$ & $\begin{array}{l}(\mathrm{a}+\mathrm{b}) \times \\
(\mathrm{b}+\mathrm{d}) / \mathrm{N}\end{array}$ & $\begin{array}{l}(c+d) \times \\
(a+c) / N\end{array}$ & $\begin{array}{l}(\mathrm{c}+\mathrm{d}) \times \\
(\mathrm{b}+\mathrm{d}) / \mathrm{N}\end{array}$ \\
\hline$* 03$ & 0.051 & 1.56 & 2.20 & 5.95 & 6.46 & 52.05 & 52.95 \\
\hline$* 04$ & 0.013 & 0.36 & 2.07 & 1.49 & 1.54 & 56.51 & 57.49 \\
\hline$* 07$ & 0.154 & 8.21 & 3.31 & 17.85 & 22.46 & 40.15 & 40.85 \\
\hline$* 08$ & 0.047 & 5.05 & 5.24 & 5.45 & 6.21 & 52.55 & 53.45 \\
\hline$* 12$ & 0.013 & 0.36 & 2.07 & 1.49 & 1.54 & 56.51 & 57.49 \\
\hline$* 20$ & 0.013 & 0.36 & 2.07 & 1.49 & 1.54 & 56.51 & 57.49 \\
\hline *22 & 0.131 & 11.11 & -4.66 & 14.87 & 11.03 & 43.13 & 43.87 \\
\hline$* 24$ & 37 & 4.52 & -2.96 & 10.41 & 8.97 & 47.59 & 48.41 \\
\hline *27 & 0.026 & 2.74 & -5.28 & 2.97 & 2.82 & 55.03 & 55.97 \\
\hline$* 28$ & 0.034 & 1.03 & -2.08 & 4.46 & 4.31 & 53.54 & 54.46 \\
\hline *35 & 0.013 & 3.03 & -7.25 & 1.49 & 1.44 & 56.51 & 57.49 \\
\hline$* 43$ & 0.013 & 3.13 & 7.51 & 1.49 & 1.59 & 56.51 & 57.49 \\
\hline$* 45$ & 0.017 & 4.21 & 9.83 & 1.98 & 2.15 & 56.02 & 56.98 \\
\hline
\end{tabular}

Note: * the Table shows the alleles for which one of the following conditions is met: 1$\left.) \chi^{2} \geq 3.8 ; 2\right) \mathrm{RR} \geq 2$ or $\mathrm{RR} \leq-2 ; 3$ ) both conditions 1 and 2 are met.

Thus, in the investigated population of the Ukrainian red-pied dairy breed, two alleles have a close association with cow susceptibility to mastitis:

$* 07\left(\mathrm{RR}=3.31 ; \mathrm{P}(\mathrm{A})=0.154 ; \chi^{2}=8.21\right) ; \chi_{\min }^{2}=$ true; $* 08\left(\mathrm{RR}=5.24 ; \mathrm{P}(\mathrm{A})=0.047 ; \chi^{2}=5.05\right) ; \chi_{\text {min }}^{2}=$ true; and two alleles indicate resistance to the disease:
*22 $\left(\mathrm{RR}=-4.66 ; \mathrm{P}(\mathrm{A})=0.131 ; \chi^{2}=11.1\right) ; \chi_{\min }^{2}=$ true;

*24 (RR $\left.=-2.96 ; \mathrm{P}(\mathrm{A})=0.087 ; \chi^{2}=4.16\right): \chi_{\min }^{2}=$ true;

In further studies, it will be necessary to pay attention to the allele BoLA-DRB3. $2 * 03\left(\mathrm{RR}=2.2 ; \mathrm{P}(\mathrm{A})=0.051 ; \chi_{\text {min }}^{2}=\right.$ true $)$, for which the null hypothesis $\left(\chi^{2}=\right.$ false $)$ is not confirmed and BoLA-DRB3.2*45, which is practically not manifested in cows resistant to mastitis.

\section{Discussion}

In our study we established that high allele diversity of BoLADRB3 gene is characteristic for UBPD livestock. This breed has a diverse genetic structure. Most researchers identify this breed as an open population. The UBPD cattle have similarity to Dutch, Estonian, Lithuanian, Moscow, black and red and other breeds. Nowadays when crossbreeding with Holstein bulls is spreading actively, the presence of 32 alleles BoLA-DRB3.2 is fully consistent with its genealogy. The same large number of RLFP-alleles has been found in Mongolian (35 alleles) and Kalmyk (34 alleles) breeds (Ruzina et al., 2010), as well as Iranian Sistani (30 alleles) cattle (Behl et al., 2009).

The Ukrainian red-pied dairy breed is the second commonest dairy breed in Ukraine after the black-pied one. It is derived from reproductive crossbreeding of the Simmentals (maternal breed) with red-pied Holstein. The breed develops according to the principle of open populations and also has a heterogeneous structure. In our study, 22 alleles were detected in URPB, which is significantly less than in UBPB. This result of our study is caused by limited range and the small sample size. Most commercial breeds have a wide range of alleles - from 13 in Canadian Jersey to 28 in Iranian Holstein (Behl et al., 2009). This number of alleles in these populations is likely a consequence of maternal breed features and selection actions.

There is a low consolidation of "informative" alleles for UBPD cattle $(50.4 \%)$. The same low level of consolidation was found for UBPB (64.5\%). Commercial breeds, as a rule, are characterized by a higher consolidation of "informative" alleles. For example, there are seven alleles *22 and *24 (14.3\%), *08 (14.1\%), *16 (10.0\%), *23 (9.1\%), $* 11(8.5 \%)$ and $* 07(5.3 \%)$ with a frequency of more than $5 \%$ in Holstein cows $(n=1100)$ from 93 dairy herds in the states of Iowa, Wisconsin, Minnesota and Illinois (USA) (Dietz et al., 1997). Their sum is $75.6 \%$. Similar studies in the Holstein cows $(n=835)$ in Ontario (Canada) (Sharif et al., 1998) showed that seven "informative" alleles *08 $(20.1 \%), * 24(19.2 \%), * 11(14.9 \%), * 22(13.7 \%), * 16(9.2 \%), * 23(6.4 \%)$ and $* 03(5.2 \%)$ occupied $88.7 \%$ of the allelic spectrum. In another study carried out on Iranian Holstein cows, the most frequent alleles were BoLA-DRB3. $2 * 08, * 11, * 16$ and *24 (Mohammadi et al., 2009).

Our study has identified alleles of cows susceptible and resistance UBPD and UBPB to mastitis. Significant research was carried out (Table 5) in detecting associations between alleles BoLA-DRB 3.2 and various aspects of mastitis, such as clinical and subclinical forms, specific pathogens (Staphylococcus aureus, Streptococcus agalactiae, E. coli) and somatic count cells (Dietz et al., 1997; Kelm et al., 1997; Sharif et al., 1998, 2000; Rupp et al., 2007; Duangjinda et al., 2009; Ruzina et al., 2010; Ibrahim et al., 2012).

Sulimova, Ruzina et al. (2010) believes that generalization and analysis research of different authors indicate three groups of alleles BoLADRB3.2 in connection with mastitis: susceptibility $-* 16, * 23$ and $* 26$; resistance $-* 07, * 11, * 13, * 18$ and $* 27$; have opposite associations in different studies $-* 08, * 22$ and $* 24$. Data indicate that alleles in differrent populations have opposite associations more: *11, *16, *22, *23 and $* 24$. The conditions for the emergence of mastitis are very diverse. Many factors promote the development of mastitis, including the feeding environment, care conditions and genetic background. Infectious mastitis occurs because of the penetration of the udder by Streptococcus, Staphylococcus, coliform bacterium and other pathogens. Infection of the udder occurs through the galactogenous path (through the teat channel), the lymphogenous way (through the wounds of the teats and udder), less often by the hematogenous way (from other organs). Noninfectious mastitis is widespread. It occurs when milking is done incorrectly, when poor hygiene of the udder is maintained, when damaged milking equipment is used, etc. In milk of cows with mastitis, due to the 
development of the immune response to inflammation, SCC increases. Multifactorial effects influence different types of immune responses, which implies the peculiarity of its formation in different populations of cattle. Therefore, the possibility of finding deterministic BoLA-DRB3.2 alleles indicating resistance or susceptibility of cows to mastitis is unlikely for the whole world dairy herd.

\section{Table 5}

Summary of data on the detection of associations between alleles BoLA-DRB3.2 and various aspects of mastitis

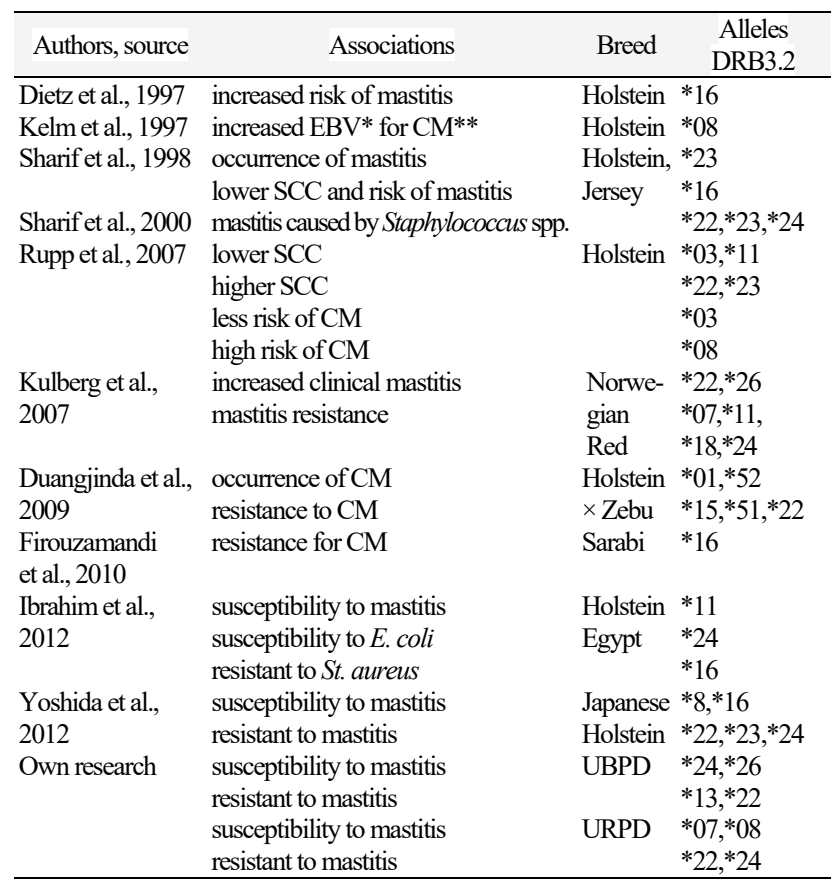

Note: $* \mathrm{EBV}$ - estimated breeding value; ${ }^{*} \mathrm{CM}$ - clinical mastitis.

Our study has identified alleles associated with mastitis which are different from alleles identified by other researchers in similar studies. This is due to the multifactoral nature of the immune response to various pathogens that cause mastitis. The condition for the emergence of mastitis is not only the penetration of the pathogen into the udder, but also its ability to survive there, and then to multiply in sufficient quantities to cause the disease. Therefore, in cases of occurrence of mastitis the natural resistance of an organism of the animal and the mammary gland is of great importance.

\section{Conclusions}

The results obtained in this study confirmed the hypothesis of DRB3 being a marker for susceptibility (resistance) to mastitis in dairy cows. In summary, it is necessary to note that the results of this study demonstrated that BoLA-DRB3.2 in the Ukrainian black-pied and the Ukrainian red-pied breeds of dairy cattle is highly polymorphic and depends on the breed and population, as a result of the founder population and selection actions. The identified BoLA-DRB3.2 alleles can be recommended as a marker used to select the animals at a young age preceding the appearance of the traits of interest for the investigated breeds. Selection of cows for resistance to mastitis with the help of DNA markers based on the alleles of the BoLA-DRB3 gene is much more effective than treatment and use of costly animal maintenance and care. Similar research should be continued in order to achieve significant results that could be applied to one breed and one disease.

\section{References}

Abdel Hameed, K. G., Sender, G., \& Mayntz, M. (2006). Major histocompatibility complex polymorphism and mastitis resistance - A review. Animal Science Papers and Reports, 24(1), 11-25.
Behl, J. D., Verma, N. K., Behl, R., \& Sodhi, M. (2009). Genetic variation of the major histocompatibility complex DRB3.2 locus in the native Bos indicus cattle breeds. Asian-Australasian Journal of Animal Sciences, 22(11), 1487-1494.

Behl, J. D., Verma, N. K., Tyagi, N., Mishra, P., Behl, R., \& Joshi, B. K. (2012) The major histocompatibility complex in bovines: A review. ISRN Veterinary Science, article ID 872710.

Chajkova, O. I., \& Foshhij, M. D. (2016). Analiz rynku molochnoi' galuzi Ukrai'ny ta prognoz jogo rozvytku [Market analysis of the dairy industry of Ukraine and forecast of its development]. Bulletin of National Technical University "Kharkiv Polytechnic Institute" (Economic Sciences), 47, 26-29 (in Ukrainian).

Dietz, A. B., Cohen, N. D., Timms, L., \& Kehrli, M. E. (1997). Bovine lymphocyte antigen class II alleles as risk factors for high somatic cell counts in milk of lactating dairy cows. Journal of Dairy Science, 80(2), 406-412.

Duangjinda, M., Buayia, D., Pattarajinda, V., Phasuk, Y., Katawatin, S., Vongpralub, T., \& Chaiyotvittayakul, A. (2009). Detection of bovine leukocyte antigen DRB3 alleles as candidate markers for clinical mastitis resistance in Holstein $\times$ Zebu. Journal of Animal Science, 87, 469-476.

Duangjinda, M., Jindatajak, Y., Tipvong, W., Sriwarothai, J., Pattarajinda, V., Katawatin, S., \& Boonkum, W. (2013). Association of BoLA-DRB3 alleles with tick-borne disease tolerance in dairy cattle in a tropical environment. Veterinary Parasitology, 196(3-4), 314-320.

Firouzamandi, M., Shoja, J., Bazegari, A., \& Roshani, E. (2010). Study on the association of BoLA-DRB3.2 alleles with clinical mastitis in Iranian Holstein and Sarabi (Iranian native) cattle. African Journal of Biotechnology, 9(15), 2224-2228.

Gilliespie, B. E., Jayarao, B. M., Dowlen, H. H., \& Oliver, S. P. (1999). Analysis and frequency of bovine lymphocyte antigen DRB3.2 alleles in Jersey cows. Journal of Dairy Science, 82, 2049-2053.

Giovambattista, G., Ripoli, M. V., Peral-Garcia, P., \& Bouzat, J. L. (2001). Indigenous domestic breeds as reservoirs of genetic diversity: The Argentinean Creole cattle. Animal Genetics, 32, 240-247.

Hanjejev, V. V., \& Janchuk, T. V. (2011). Zahvorjuvannja koriv na mastyt: Rahujemo zbytky [Disease of cows for mastitis: Count losses]. Veterynarna Medycyna Ukrai'ny, 189, 36-37 (in Ukrainian).

Ibeagha-Awemu, E. M., Kgwatalala, P., Ibeagha, A. E., \& Zhao, X. (2008). A critical analysis of disease-associated DNA polymorphisms in the genes of cattle, goat, sheep, and pig. Mammalian Genome, 19, 226-245.

Ibrahim, E. A., Allam, N. A. T., Kotb, E. E. Z., El-Rafey, G. A., El-Deen, M. M. A., \& Fadlallah, M. G. (2012). Sequence-based typing-study on the relationship between subclinical mastitis and BoLA-DRB3.2* allelic polymorphism in Egyptian cows. Global Veterinaria, 9(1), 8-22.

Kelm, S. C., Detilleux, J. C., Freeman, A. E., Kehrli, M. E., Dietz, A. B., Fox, L. K., Butler, J. E., Kasckovics, I., \& Kelley, D. H. (1997). Genetic association between parameters of inmate immunity and measures of mastitis in periparturient Holstein cattle. Journal of Dairy Science, 80, 1767-1775.

Kleinbaum, D. G., Kupper, L. L., \& Morgenstern, H. (1982). Epidemiologic research lifetime learning publication. Lifetime Learning Publications, Belmont.

Kulberg, S., Heringstad, B., Guttersrud, O. A., \& Olsaker, I. (2007). Study on the association of BoLA-DRB3.2 alleles with clinical mastitis in Norwegian Red cows. Journal of Animal Breeding and Genetics, 124(4), 201-217.

Latypova, Z., Sarbakanova, S., Mamanova, S., Sultanov, A., Nam, I., Smaznova, I., Zayakin, V., \& Kozlov, A. (2017). Comparison between populations of black pied and holstein cows and stud bulls from Russia, Belarus and Kazakhstan by the genetic markers for resistance to leukemia. International Journal of Current Research in Biosciences and Plant Biology, 4(8), 1-7.

Lei, W., Liang, Q., Jing, L., Wang, C., Wu, X., \& He, H. (2012). BoLA-DRB3 gene polymorphism and FMD resistance or susceptibility in Wanbei cattle. Molecular Biology Reports, 39(9), 9203-9209.

Maillard, J. C., Martinez, D., \& Bensaid, A. (1996). An amino acid sequence encoded by the exon 2 of the BoLA-DRB3 gene associated with a BoLA class 1 specificity constitutes a likely genetic marker of resistance to dermatophilosis in Brahman zebu cattle in Martinique (FWI). Annals of the NY Academy of Science, 791, 185-197.

Mohammadi, A., Nassiry, M. R., Mosafer, J., Mohammadabadi, M. R., \& Sulimova, G. E. (2009). Distribution of BoLA-DRB3 allelic frequencies and identification of a new allele in the Iranian cattle breed sistani (Bos indicus). Russian Journal of Genetics, 45(2), 224-229.

Nikbakht Brujeni, G., Ghorbanpour, R., \& Esmailnejad, A. (2016). Association of BoLA-DRB3.2 alleles with BLV infection profiles (Persistent lymphocytosis / Lymphosarcoma) and Lymphocyte Subsets in Iranian Holstein Cattle. Biochemical Genetics, 54(2), 194-207.

Rupp, R., Hernandez, A., \& Mallard, B. (2007). Association of bovine leukocyte antigen (BoLA) DRB3.2 with immune response, mastitis, and production and type traits in Canadian Holsteins. Journal of Dairy Science, 90(2), 10291038.

Ruzina, M. N., Shtyfurko, T. A., Mohammad Abadi, M. R., Gendzhieva, O. B., Cedev, C., \& Sulimova, G. E. (2010). Polimorfizm gena BoLA DRB 3 u 
krupnogo rogatogo skota mongol'skoj, kalmyckoj i jakutskoj porod [Polymorphism of the BoLA-DRB3 gene in the Mongolian, Kalmyk, and Yakut Cattle Breeds]. Russian Journal of Genetics, 46(4), 517-525 (in Russian).

Sharif, S., Mallard, B. A., Wilkie, B. N., Sargeant, J. M., Scott, H. M., Dekkers, J. C. \& Leslie, K. E. (1998). Associations of the bovine major histocompatibility complex DRB3 (BoLA-DRB3) alleles with occurrence of disease and milk somatic cell score in Canadian dairy cattle. Animal Genetics, 29, 185-193.

Sharif, S., Mallard, B. A., \& Sargeant, J. M. (2000). Presence of glutamine at position 74 of pocket 4 in the BoLA-DR antigen-binding groove is associated with occurrence of clinical mastitis caused by Staphylococcus species. Veterinary Immunology and Immunopathology, 76, 231-238.

Sulimova, G. E. (2004). DNK-markery v geneticheskih issledovanijah: Tipy markerov, ih svojstva i oblasti primenenija [DNA markers in genetic research: Marker types, their properties and applications]. The Success of Modern Biology, 124(3), 260-271 (in Russian).

Sun, L., Song, Y., Riaz, H., \& Yang, L. (2013). Effect of BoLA-DRB3 exon 2 polymorphisms on lameness of Chinese Holstein cows. Molecular Biology Reports, 40(2), 1081-1086.

Takeshima, S. N., Giovambattista, G., Okimoto, N., Matsumoto, Y., RogbergMuñoz, A., Acosta, T. J., Onuma, M., \& Aida, Y. (2015). Characterization of bovine MHC class II DRB3 diversity in South American Holstein cattle populations. Tissue Antigens, 86(6), 419-430.

Takeshima, S., Nakai, Y., Ohta, M., \& Aida, Y. (2002). Characterization of DRB3 alleles in the MHC of Japanese Shorthorn cattle by polymerase chain reaction sequence based typing. Journal of Dairy Science, 85, 1630-1632.

Takeshima, S. N., Miyasaka, T., Polat, M., Kikuya, M., Matsumoto, Y., Mingala, C. N., Villanueva, M. A., Salces, A. J., Onuma, M., \& Aida, Y. (2014). The great diversity of major histocompatibility complex class II genes in Philippine native cattle. Meta Gene, 2, 176-190.

Udina, I. G., Karamysheva, E. E., Turkova, S. O., Sulimova, G. E., \& Orlova, A. R. (2003). Genetic mechanisms of resistance and susceptibility to leukemia in Ayrshire and Black-pied cattle breeds determined by allelic distribution of gene BoLA-DRB3. Genetika, 39(3), 306-317.

Van Eijk, M. J. T., Stewart-Haynes, J. A., \& Lewin, H. A. (1992). Extensive polymorphism of the BoLA-DRB3 gene distinguished by PCR-RFLP. Animal Genetics, 23(6), 483-496.

Yoshida, T., Furuta, H., Kondo, Y., \& Mukoyama, H. (2012). Association of BoLA-DRB3 alleles with mastitis resistance and susceptibility in Japanese Holstein cows. Animal Science Journal, 83(5), 359-366.

Zaretskaya, Y. M. (1983). Klinicheskaja immunogenetika [Klinicheskaya immunogenetika]. Meditsina, Moscow. Pp. 70-74 (in Russian). 